International Journal of English Literature and Social Sciences
Vol-6, Issue-5; Sep-Oct, 2021

Peer-Reviewed Journal

\title{
A Critical Analysis of the Novel A Passage to India by E.M. Forster
}

\author{
Nidhi Singh Chauhan
}

Barkatullah University, Bhopal, M.P., India.

Received: 03 Aug 2021; Received in revised form: 06 Sep 2021; Accepted: 14 Sep 2021; Available online: 22 Sep 2021

(C2021 The Author(s). Published by Infogain Publication. This is an open access article under the CC BY license

(https://creativecommons.org/licenses/by/4.0/).

\begin{abstract}
Forster's masterpiece work, 'A Passage to India' gives the description of the scene of society in India under the British rule. Clashes between East and West cultures and the prejudiced misunderstandings in this novel are worth mentioning. There is criticism for anti-British in inaccurate bias but praised for a good character study of Indians by the writer. Forster is certainly influenced by English social and cultural circumstances but he depicts, sympathy and judgement, the complicated oriental reaction to British rule in India and reveals the conflict of temperament and tradition involved in the relationship.
\end{abstract}

Keywords- Scepticism, Hegemony, Prejudice, Colonizer, Egocentricity, Patriarchy, Ambivalence Hinduism.

Several novels were portrayed during the British rule in India. A Passage to India is most prominent among them. It was written by E.M.Forster on his first-hand experience of India. It depicts the colonizer-colonized relationship during colonial rule. Forster pictured cultural and religious differences between Indians and English people who were ruling in India through several incidences in the novel. He also showed, the ambivalence in the colonizer- colonized relationship in the novel.

According to Brenda Silver [4] A passage to India is:

"a study of what it means to be rapable, a social position that cuts across biological and racial lines to inscribe culturally constructed definitions of sexuality within a sex/gender/power system".

Tayeb [5] describes it as:

"A Passage to India studies the viability of transcending the encumbrances of the colonial situation, on the part of both the colonialist and the native, in order to set up new formulas of social interaction and crosscultural exchange".

'Mr. Forster's new novel is not only much the best of the three he has written, but it clearly admits him to the limited class of writers who stand above and apart from the manufacturers of contemporary fiction."-Spectator.

"It is packed with wonderful impressions and radiant sayings."-Evening Standard.

"This is one of the cleverest and most entertaining novels we have read for some time. The characters are as clear and salient as a portrait by Sargent, and there are many of them. One is continually moved to appreciative smiles by clever little touches of description and enlightenment. The story, too, is interesting and real."Daily Mail.

"This odd title suggests a story rather out of the common, and it does not prove in the least misleading. The book is both original and delightful, presenting scenes of everyday life almost commonplace sometimes in their fidelity to nature, but chronicled in such a happy vein of quiet humour and with such penetrating observation as makes each little incident and dialogue a source of sheer joy to the reader. The characters are admirably drawn."-Pall Mall Gazette. "We have originality and observation, 
and a book as clever as the other books that $\mathrm{Mr}$. Forster has written already."-Times.

Writer explores the discrimination of Indians by the English. In the Chandrapore club Indians are not allowed. "Indians are not allowed into the Chandrapore Club even as guests" (19). He also gives the details of other misbehaviours of the English. Hegemonic practices were adopted in British Raj. "Take the gifts the gods provide, anyhow"(10). Epistemological techniques helped the English to control Indians. They used ideology ethnology and anthropology to make their empire powerful. Writer ignores the issues of scepticism of Indians towards the colonial forces.

Edward Morgan Forster (1 January 1879 - 7 June 1970) was a well-known British novelist, essayist and short story writer. A Passage to India is considered as Forster's best work which is the result of Forster's two journeys to India in 1912 and 1922. This was published in 1924 and won the James Tait Black Memorial Prize in the same year. Forster wrote only six novels, in which his controversial novel Maurice on homosexuality was published in 1971, a year after Forster's death. He never finished his seventh novel Arctic Summer. He wrote literary criticism and nonfiction, including biographies, histories, political pieces, and radio broadcasts. A Passage to India was adapted as a play in 1960, directed by Frank Hauser, and as a film in 1984, directed by David Lean. He mainly worked on three genres - realism, symbolism and modernism. Realism (also called naturalism) is the accurate and precise representation of scenes and objects in the literature. Mimicry is a good example of realism. Symbolism originated from poetry to represent absolute truths symbolically through metaphorical images and language. It is opposite to realism and used in spirituality, the imagination and dreams. Symbolists' symbols are not allegories, but intended to evoke particular states of mind. Wearing of cloths is an example of symbolism. Modernism is a desire for the creation of new forms of art, philosophy and social organization. It represents the newly emerging industrial world, with its features like urbanization, new technologies, fashion and war. Modernists attempt to depart from traditional forms of art, which they consider outdated or obsolete. Ezra Pound's slogan "Make it new!" became the touchstone of the movement.

The theme of the novel revolves around two British women, Adela and Mrs Moore, who question the standard behaviours of the English toward the Indians. Both women want to see the 'real India'. Mrs. Moore is a kind-hearted, spiritual, mature woman with magical leanings. Mrs Moore is the mother of Adela's intended bridegroom, Ronny Heaslop. Ronny Heaslop is Mrs Moore's son from her first marriage. $\mathrm{He}$ is the City magistrate at hypothetical city Chandrapore(the anglicised spelling of Chandrapur) in north-eastern India. In the starting of the novel, we get introduced to the Marabar Caves and Chandrapore.. The view of the writer about India can be understood by the imagination of the place Chandrapore:

Chandrapore was never large or beautiful, but two hundred years ago it lay on the road between Upper India, then imperial, and the sea, and the fine houses date from that period. The zest for decoration stopped in the eighteenth century, nor was it ever democratic. There is no painting and scarcely any carving in the bazaars. The very wood seems made of mud, the inhabitants of mud moving. So abased, so monotonous is everything that meets the eye, that when the Ganges comes down it might be expected to wash the excrescence back into the soil. Houses do fall, people are drowned and left rotting, but the general outline of the town persists, swelling here, shrinking there, like some low but indestructible form of life.

...Beyond the railway- which runs parallel to the river- the land sinks, then rises again rather steeply. On the second rise is laid out the little civil station, and viewed hence Chandrapore appears to be a totally different place. It is a city of gardens. It is no city, but a forest sparsely scattered with huts. It is a tropical pleasance washed by a noble river. The toddy palms and neem trees and mangoes and pepul that were hidden behind the bazaars now become visible and in their turn hide the bazaars. They rise from the gardens where ancient tanks nourish them, they burst out of stifling purlieus and unconsidered temples. Seeking light and air, and endowed with more strength than man or his works, they soar above the lower deposit to greet one another with branches and beckoning leaves, and to build a city for the birds.

Especially after the rains do they screen what passes below, but at all times, even when scorched or leafless, they glorify the city to the English people who inhabit the rise, so that new-comers cannot believe it to be as meagre as it is described, and have to be 
driven down to acquire disillusionment. (PI 31- 32)

Adela intends to see Ronny Heaslop before marriage. Initially Mrs Moore was very satisfied with his journey in India but in the second part of the novel, she becomes pessimist after visiting the cave. Although her approach and mentality to the world also conditioned by the sensibility of western civilization but unlike other English people in the story, they want to impose their British categories on other nations. Mrs. Moore is more open to the world. Therefore, after experiencing the echo in the cave, she leaves all of her willingness and expectation. "Though provoking a little disappointment at first, the gradual disclosure of the character of Mrs. Moore unveils her venerable wisdom and receptive magnanimity"(Tayeb 44).

Mr Cyril Fielding, Mrs Moore and Miss Adela are not happy by seeing that there is big gap between the British community and the Indian population. Mrs Moore and Miss Adela hey are worried by growing Indian independence movement in the 1920s. But they feels some relief when the local school superintendent Cyril Fielding brings into their acquaintance the eccentric elderly Hindu Brahmin scholar Professor Narayan Godbole. A Muslim widower, Dr Aziz Ahmed also meets with Mrs Moore in a mosque who is also local Indian. Writer has pictured this incidence as:

“"Madam! Madam! Madam!" "Oh! Oh!" the woman gasped.

"Madam, this is a mosque, you have no right here at all; you should have taken off your shoes; this is a holy place for Moslems."

"I have taken them off." "You have?"

"I left them at the entrance." "Then I ask your pardon."

Still startled, the woman moved out, keeping the ablution-tank between them. He called after her, "I am truly sorry for speaking."

"Yes, I was right, was I not? If I remove my shoes, I am allowed?"

"Of course, but so few ladies take the trouble, especially if thinking no one is there to see." (PI 42)"

This incident shows the cultural difference between the two races. Aziz took it for granted that Englishwoman would enter in the mosque without taking off her shoes to insult his religion. Such type of presumptions about each other created barriers for the development of relationships between colonizers and colonized. Here Aziz was wrong about Mrs. Moore as she has already taken off her shoes. The attitude of the colonizers towards the Indians is the result of cultural differences as well as of power positioning. Lamina Tayeb [5] writes:

"Through his depiction of the Indian setting, Forster stresses the alienating features of the land. From the point of view of the colonizer, these are the elements that make alterity so remote, alien and intransigent. They are what makes the exploring newcomer sail back in horror, forever dropping the possibility of adaptation and integration. The emphasis on the sinister and the ominously impending in the atmosphere denotes the inherent incompatibility of the Indian environment for social and cultural exchange. The ordinary and the horribly repulsive features conjoin and blend to produce a marred image of the East that is - like the echo in the Marabar Caves... and so empty of promise for an eternally estranged colonizer."

After knowing intentions of foreign ladies to visit India, Dr Aziz offers to host an excursion to the local Malabar caves. Mrs. Moore suffers from claustrophobia. Claustrophobia is a disease in which a person suffering from it may have an anxiety attack, therefore, Mrs Moore encourages Adela and Aziz to continue their exploration of the caves with the guide. Before entering the caves, Adela asks Aziz about any wife other than one who passed away. Aziz shocked by Adela's question, therefore steps away to smoke a cigarette to remove his tension. After returning, he finds that Adela has disappeared and sees her running headlong down the hill, dishevelled. Adela is picked up by the doctor's wife, Mrs Callendar, and taken to the Callendar's home. Adela is injured; therefore, blood spots are visible on her head. Dr Aziz is arrested for the charge of attempting to rape Adela at the caves and is jailed to await trial. Mrs Moore firmly believes that Dr Aziz cannot do such offence therefore she is very sad and ready to support Aziz at time of trial. But his son forced her to leave India so that she could not appear during the trail. Unfortunately, she dies during the journey. Adela denied her earlier accusation of attempt of rape by Dr Aziz and said that was her illusion due to claustrophobia. In this way Aziz is celebrated for his innocence and Adela is abandoned to her own devices by the British except for Mr Fielding. Mr Fielding assists her to safety at the college and returns to England at the earliest with Adela. Dr Aziz becomes sad by the help 
rendered by Mr Fielding to Adela even after knowing the misbehaviour of Adela with him and the friendship between them ends. Dr Aziz decides not to believe on English person in future and goes in another Indian state Kashmir to open his clinic in the lake area near Srinagar. At the time of return journey of Fielding and Adela, Dr Aziz thinks that both are going to marry with each other but after some time Fielding married with Stella Moore, Mrs Moore's daughter from her second marriage. Then Dr Aziz ultimately reconciles with Fielding, and also asks Adela to forgive him for taking so long time to come to appreciate the courage that she exercised when she withdrew her accusation in court.

Religion is also a significance issue of conflict in the novel. Dr Aziz and Mrs Moore advocate their religions. "Here was Islam, his own country, more than a Faith, more than a battle-cry, more, much more . . Islam, an attitude towards life both exquisite and durable, where his body and his thoughts found their home" (23). Mrs Moore and Adela escape from the question of apathy. "she was sunk in apathy and cynicism. The wonderful India of her opening weeks with its cool nights and acceptable hints of infinity, had vanished" (25).

and Islamic poems respectively through Godbole and Aziz. Godbole sings a Bhakti song on the request of Mrs. Moore and explained the lyric to the ladies.

It was a religious song. I placed myself in the position of a milkmaiden. I say to Shri Krishna, "Come! Come to me only." The god refuses to come. I grow humble and say: "Do not come to me only. Multiply yourself into a hundred Krishnas, and let one go to each of my hundred companions, but one, O Lord of the Universe, come to me." He refuses to come. This is repeated several times. The song is composed in a raga appropriate to the present hour, which is the evening. (PI 96)

Aziz recites some poems of

the Muslim writer:

Aziz began quoting poetry: Persian, Urdu, a little Arabic. His memory was good, and for so young a man he had read largely; the themes he preferred were the decay of Islam and the brevity of Love. They listened delighted, for they took the public view of poetry, not the private which obtains in England. It never bored them to hear words, words; they breathed them with the cool night air, never stopping to analyse; the name of the poet, Hafiz, Hali, Iqbal, was sufficient guarantee. (PI 37-38)

Lake of respect of the English to Indians can be seen everywhere. Tayeb writes:

This presumptive superiority is what invalidates the establishment of a hybrid friendship and forbids the settler to overstep the boundaries of the colonial selfsequestered herd. Those who dare contravene these colonial norms must, on the one hand, undergo the volatility and unpredictability of such a cross- cultural approach, and accommodate the quailing responses of the colonized. On the other hand, they bear the brunt of their countrymen's grudge and acrimony, as well as the slur of disloyalty.

Fielding mocks Aziz about his nationalist view as:

he (Aziz) shouted: "India shall be a nation! No foreigners of any sort! Hindu and Moslem and Sikh and all shall be one! Hurrah! Hurrah for India! Hurrah! Hurrah!"

India a nation! What an apotheosis! Last comer to the drab nineteenth- century sisterhood! Waddling in at this hour of the world to take her seat! She, whose only peer was the Holy Roman Empire, she shall rank with Guatemala and Belgium perhaps! Fielding mocked again. (PI 315)

In reply to Fielding's insulting statement, Aziz responded as:

"Down with the English anyhow. That's certain. Clear out, you fellows, double quick, I say. We may hate one another, but we hate you most. If I don't make you go, Ahmed will, Karim will, if it's fifty-five hundred years we shall get rid of you, yes, we shall drive every blasted Englishman into the sea, and then "--he rode against him furiously-"and then," he concluded, half kissing him, "you and I shall be friends." (PI 315-16)

Cultural differences and misunderstanding of both races are also visible in the novel. These are the main hardships to bridge the gulf of cultures.

Her impressions were of no interest to the Collector; he was only concerned to give her a good time. Would she like a Bridge Party? He explained to her what that was-not the

game, but a party to bridge the gulf between East and West; the expression was his own invention, and amused all who heard it 
"I only want those Indians whom you come across socially — as your friends."

"Well, we don't come across them socially," he said, laughing. "They're full of all the virtues, but we don't, and it's now eleven-thirty, and too late to go into the reasons."

Forster investigates the cross-cultural friendship between the English and Indians. In the beginning he produces Fielding and Dr Aziz as example of goodwill, intelligence and respect to each other but in the last they hate to each other.

The racist attitude of Anglo-Indians can also be observed in the novel. Timothy Christensen [6] says:

When Mrs. Moore attempts to overcome the hostility between Indians and English through a sympathetic identification with Aziz at the begin-ning of the novel, she exposes the inadequacy of this doctrine. Despite her good intentions, she is struck by the accuracy of her son Ronny Heaslop's unflattering description of Aziz as she recalls her initial meeting with Aziz in the mosque. (Christensen, 163)

Mr. Mc Bryde gives most racist statement of this novel.

Oriental Pathology, his favourite theme, lay around him, and he could not resist it. Taking off his spectacles, as was his habit before enunciating a general truth, he looked into them sadly, and remarked that the darker races are physically attracted by the fairer, but not vice versa - not a matter for bitterness this, not a matter for abuse, but just a fact which any scientific observer will confirm. (PI 222)

Forster condemns the bad behaviours of colonisers to the colonised in his writings. Therefore, his name is included in the category of librettists. His novels are ironic and well-plotted. He describes the class differences and hypocrisy in his writings. A Passage to India became most controversial but gave him the greatest success. Forster fought against the restrictions which the English imposed on individual liberty.

The patriarchy can be seen throughout the novel. The thoughts of Dr. Aziz toward his belated wife are accompanied by a sense of inferiority. He has no respect for his wife. He shares the photograph of his wife to his Anglo-Indian friend, Mr. Fielding. Mr. Fielding appreciates his Indian friend for sharing the picture of his wife "Oh, it's nothing, she was not a highly educated woman or

even beautiful, but put it away. You would have seen her, so

why should you not see her photograph?"

"You would have allowed me to see her?"

"Why not? I believe in the purdah, but I should have told

her you were my brother, and she would have seen you.

Hamidullah saw her, and several others."

"Did she think they were your brothers?"

"Of course not, but the word exists and is convenient. All

men are my brothers, and as soon as one behaves as such

he may see my wife."

"And when the whole world behaves as such, there will be

no more purdah?"

"It is because you can say and feel such a remark as that,

that I show you the photograph," said Aziz gravely.(128-129).

Their speech exposes that women are the centre point of the men's conversation.

Traditional narrative method of the omniscient narrator is used in the novel. Narrator speaks from the side of characters. He also sets the tone of each section of the novel.

\section{CONCLUSION}

Forster fairly portrays the passage where the English and Indian can meet and live together respecting to each other. He advocates the way of harmony to the English and Indians to live together happily but does not outrightly says to British to leave India. Writer prays to God to establish friendship between two races and to remove the hurdles in this task. Novel explores the consequences of mixing two cultures. The human failure is clearly shown to eliminate the prejudices among people from two races. 


\section{REFERENCES}

[1] Brower, Reuben. The Fields of Light: An Experiment in Critical Reading. New York: Oxford University Press, 1951.

[2] Chaudhuri, Nirad C. Passage To and From India, Encounter. New York: Harcourt, Brace and Company, 1954.

[3] Forster, E. M. A Passage to India. New York: Penguin Classics, 1986

[4] Silver, Brenda. 'Periphrasis, Power, and Rape in A Passage to India', Novel, 22 (1988), p.p.86-105.

[5] Tayeb, Lamia. "The Inscription of Cultural Bafflement in E. M. Forster's A Passage to India"'. Interdisciplinary Literary Studies, Vol. 6, No. 1 (2004), pp. 37-59

[6] Timothy Christensen. "Bearing the White Man's Burden: Misrecognition and Cultural Difference in E. M. Forster's "A Passage to India"", NOVEL: A Forum on Fiction in Spring, 2006. 